\title{
Genetic variation in Fc $\gamma$ receptor Ila and risk of coronary heart disease: negative results from two large independent populations
} Mahir Karakas', Michael M Hoffmann², Caren Vollmert ${ }^{3}$, Dietrich Rothenbacher ${ }^{4}$, Christa Meisinger ${ }^{3}$, Bernhard Winkelmann ${ }^{5}$, Natalie Khuseyinova ${ }^{1}$, Bernhard O Böhm ${ }^{6}$, Thomas Illig ${ }^{3}$, Winfried März ${ }^{7}$ and Wolfgang Koenig*1

\author{
Address: ${ }^{1}$ Dept. of Internal Medicine II-Cardiology, University of Ulm, Germany, ${ }^{2}$ Dept. of Clinical Chemistry, University of Freiburg, Germany, \\ ${ }^{3}$ Helmholtz Center Munich, German Research Center for Environmental Health (GmbH), Institute of Epidemiology, Germany, ${ }^{4}$ Div. of Clinical \\ Epidemiology and Aging Research, German Cancer Research Center Heidelberg, Germany, ${ }^{5}$ Cardiology Group Frankfurt-Sachsenhausen, \\ Frankfurt, Germany, ${ }^{6}$ Dept. of Internal Medicine I, University of Ulm, Germany and ${ }^{7}$ Synlab, Center of Laboratory Diagnostics, Heidelberg, \\ Germany \\ Email: Mahir Karakas - mahir.karakas@uniklinik-ulm.de; Michael M Hoffmann - michael.hoffmann@uniklinik-freiburg.de; \\ Caren Vollmert - vollmert@helmholtz-muenchen.de; Dietrich Rothenbacher - d.rothenbacher@yahoo.de; \\ Christa Meisinger - christa.meisinger@helmholtz-muenchen.de; Bernhard Winkelmann - b.winkelmann@kfsh.de; \\ Natalie Khuseyinova - natalie.khuseyinova@uniklinik-ulm.de; Bernhard O Böhm - Bernhard.Boehm@uniklinik-ulm.de; \\ Thomas Illig - illig@helmholtz-muenchen.de; Winfried März - maerz@synlab.de; Wolfgang Koenig* - wolfgang.koenig@uniklinik-ulm.de \\ * Corresponding author
}

Published: 29 May 2009

BMC Medical Genetics 2009, 10:46 doi:10.1 186/1471-2350-10-46

This article is available from: http://www.biomedcentral.com/I47/-2350/I0/46

(C) 2009 Karakas et al; licensee BioMed Central Ltd.

This is an Open Access article distributed under the terms of the Creative Commons Attribution License (http://creativecommons.org/licenses/by/2.0), which permits unrestricted use, distribution, and reproduction in any medium, provided the original work is properly cited.

\begin{abstract}
Background: The role of the $\mathrm{Fc} \gamma$ receptor Ila ( $\mathrm{Fc \gamma}$ Rlla), a receptor for $\mathrm{C}$-reactive protein (CRP), the classical acute phase protein, in atherosclerosis is not yet clear. We sought to investigate the association of FcyRlla genotype with risk of coronary heart disease (CHD) in two large populationbased samples.
\end{abstract}

Methods: FcyRlla-R/HI3I polymorphisms were determined in a population of 527 patients with a history of myocardial infarction and 527 age and gender matched controls drawn from a population-based MONICA- Augsburg survey. In the LURIC population, 2227 patients with angiographically proven $\mathrm{CHD}$, defined as having at least one stenosis $\geq 50 \%$, were compared with 1032 individuals with stenosis $<50 \%$.

Results: In both populations genotype frequencies of the FcyRlla gene did not show a significant departure from the Hardy-Weinberg equilibrium. FcyRlla $\mathrm{R}(-|\mathrm{I}|) \rightarrow \mathrm{H}$ genotype was not independently associated with lower risk of $\mathrm{CHD}$ after multivariable adjustments, neither in the MONICA population (odds ratio (OR) I.08; $95 \%$ confidence interval (Cl) 0.81 to 1.44 ), nor in LURIC (OR 0.96; $95 \% \mathrm{CI} 0.8 \mathrm{I}$ to I.I4).

Conclusion: Our results do not confirm an independent relationship between FcyRlla genotypes and risk of $\mathrm{CHD}$ in these populations. 


\section{Background}

Fcy receptors ( $F c \gamma R$ ) bind the Fc portion of immunoglobulin (Ig) and thereby link antigen recognition by antibodies with cell-based effector mechanisms [1-4]. Although FcyRIIa (or CD32) [GenBank: BC019931] is expressed on various cells involved in atherogenesis like monocytes, macrophages, platelets and neutrophils, and though it has been detected immunocytochemically in human atherosclerotic lesions, its potential active role in atherosclerosis is still a matter of controversy $[5,6]$. Calverley et al. showed Fc $\gamma$ RIIa expression to be increased in platelets of patients experiencing an acute atherothrombotic event or who were clinically healthy but had two or more atherosclerosis risk factors; by contrast, Pfeiffer et al. reported decreased expression of Fc $\gamma$ RIIa on peripheral blood monocytes in patients with severe atherosclerosis $[7,8]$.

A specific genetic polymorphism affecting its function has been described in the FcyRIIa, causing an amino acid exchange from arginine $(\mathrm{R})$ to histidine $(\mathrm{H})$ at position 131. H131 is the only FcrR that recognizes IgG2 efficiently. The codominantly expressed R131 allele has affinity for IgG3 and IgG1 subtypes and exhibits a strongly diminished binding to IgG2 [9].

Increasing evidence suggests that immune processes play a substantial role in atherosclerosis [10]. It has been hypothesized that immune complexes containing immunogenic molecules such as low-density lipoproteins (LDL), heat shock proteins, or microorganisms may activate Fc $\gamma$ RIIa within atherosclerotic plaques, subsequently leading to the production and secretion of mediators [11]. On the one hand results from the Rotterdam study have suggested that the IgG subclass specificity of the H131 allele protects against advanced peripheral atherosclerosis. Since the protective effect was independent of traditional cardiovascular risk factors, the authors suggested investigating whether the $\mathrm{H} 131$ allele also protects against clinical cardiovascular events [12].

On the other hand, Gavasso et al. assessed the relationship between polymorphisms in three different $\mathrm{F} c \gamma \mathrm{R}$ genes and coronary artery disease (CAD). In 882 patients undergoing coronary angiography, no association was found between the FcyRIIa genotypes and CAD [13].

Fc $\gamma$ RIIa has been identified as the major receptor for human C-reactive protein (CRP) [14]. Pan et al. reported the presence of Fc $\gamma$ R's on human EC and their upregulation by cytokines. They described the receptor expression in native EC's being low and getting upregulated by cytokines [15].

CRP, the classical acute phase protein, is a strong cardiovascular risk marker, and responds rapidly to various proinflammatory stimuli [16-18]. Furthermore, several recent studies also suggest a proatherogenic role for CRP. Mechanisms, in support of such a notion include the acceleration of the progression of atherosclerosis in apolipoprotein E-deficient mice, suggesting direct involvement of CRP in atherogenesis [19], and its presence in atherosclerotic lesions but not in the normal vessel wall $[20,21]$.

Devaraj et al. showed that CRP binds to Fc $\gamma \mathrm{R}$, mainly FcyRIIa on human aortic endothelial cells (HAEC) to mediate its biological activity, and incubation of HAEC with monoclonal antibodies to Fc $\gamma$ RIIa before addition of CRP markedly reversed the proatherogenic effects of CRP on prostacyclin synthase and IL-8. Similar results were observed with intercellular adhesion molecule (ICAM)-1, vascular cell adhesion molecule (VCAM)-1, cGMP and PAI-1 [22]. CRP stimulated matrix metalloproteinase-1 (MMP-1) expression in U937 histiocytes through FcyRII and extracellular signal-regulated kinase (ERK) pathway, suggesting that CRP may be involved in plaque destabilization [23].

Recently, research in this field has focused on the two allelic variants of Fc $\gamma$ RIIa. It has been shown that CRP binding is allele-specific. CRP binds with high avidity to monocytes and neutrophils from R131 homozygotes, but shows strongly decreased binding to cells from FcyRIIa H131 homozygotes and intermediate binding to FcyRIIa heterozygotes, implying that the HH131 genotype may thus be less susceptible to coronary heart disease (CHD) [24].

Since there is no direct evidence that the polymorphism may be associated with a lower risk of CHD in vivo we sought to investigate the potential association between the allelic status of FcyRIIa and risk of CHD in two large independent populations.

\section{Methods \\ Study populations \\ MONICA Study}

The MONICA (MONItoring of trends and determinants in CArdiovascular disease) Augsburg study was part of the multinational World Health Organisation MONICA project. From $1984 / 85$ to $1994 / 95$, three populationbased MONICA surveys had been conducted, and a regional myocardial infarction registry had been established. Altogether 13,427 subjects of caucasian background $(6,725$ men and 6,702 women) were prospectively followed within the frame of the KORA (Cooperative Research in the Region of Augsburg). The design of the project has been described in detail elsewhere [25]. Five hundred and twenty seven patients with a history of myocardial infarction (MI), identified from 
the Augsburg Myocardial Register 1996/97, (KORA-B), served as cases, who were compared to 527 age- and gender-matched controls drawn from the population-based MONICA Augsburg survey, conducted in 1994/95.

The presence of CHD was defined as a validated diagnosis of non- fatal and fatal MI according to MONICA diagnostic criteria [26]. Diabetes mellitus (DM) was defined by a positive history, treatment with hypoglycemic drugs or having either random plasma glucose $\geq 200 \mathrm{mg} / \mathrm{dl}$ or a HbA1c $\geq 6.5 \%$. Actual hypertension was defined as being aware of hypertension and/or having blood pressure values $\geq 160 \mathrm{~mm} \mathrm{Hg}$ systolic and/or $\geq 95 \mathrm{mg} \mathrm{Hg}$ diastolic. Baseline information on smoking habits, alcohol consumption, medical history, and body mass index (BMI) was gathered by trained medical staff during a standardized interview.

\section{LURIC Study}

A total of 3,297 patients with suspect CHD participating in the LUdwigshafen RIsk and Cardiovascular Health (LURIC) study were included in these analyses. The design of the study has been described in detail elsewhere [27]. Analyses are based on individuals from whom complete data were available $(\mathrm{n}=3,259)$. Exclusion criteria were incomplete angiographic data, missing data on any of the considered risk factors, acute infectious diseases, or evidence of malignant diseases -possibly associated with an acute phase reaction. All subjects were of caucasian background.

Thus, 2,227 patients with significant CHD were compared with 1,032 individuals with stenoses $<50 \%$ (control group). DM was diagnosed according to the criteria of the American Diabetes Association (ADA) if plasma glucose was $>1.25 \mathrm{~g} / \mathrm{L}$ in the fasting state or $2.00 \mathrm{~g} / \mathrm{L}$ two hours after an oral glucose load, which was performed in all subjects not previously diagnosed as having DM, or if individuals received oral hypoglycemic drugs or insulin. Hypertension was defined as having a systolic and/or diastolic blood pressure $>140$ and/or $90 \mathrm{~mm} \mathrm{Hg}$ or having a history of hypertension.

All subjects underwent a standardized interview conducted by trained personnel. The information obtained included current health status -especially physician diagnosed hypertension and DM, medical history, and current medication. Furthermore, sociodemographic characteristics and lifestyle habits were recorded.

Both studies have been approved by the appropriate ethics committees and have therefore been performed in accordance with the Declaration of Helsinki.

\section{Laboratory methods \\ MONICA Study}

A non-fasting venous blood sample was obtained from all study participants while sitting. Total cholesterol was determined with an enzymatic method (CHOD-PAP, Roche Diagnostics, Mannheim, Germany). LDLc was measured after precipitation with dextran sulphate (Quantolip LDL, Immuno AG, Vienna, Austria) and HDLc after precipitation with phosphatungstate acid and $\mathrm{Mg}^{2+}$ (Roche Diagnostics, Mannheim, Germany). CRP measurements were done by a high-sensitivity latex enhanced nephelometric assay on a BN II analyser (Dade Behring, Marburg, Germany).

\section{LURIC Study}

Venous blood was drawn from all participants early in the morning before cardiac catheterization. Total cholesterol was determined enzymatically. HDLc was determined after precipitation with phosphatungstate acid and $\mathrm{Mg}^{2+}$ (Roche Diagnostics, Mannheim, Germany). CRP concentrations were determined using the same high-sensitivity latex-enhanced nephelometric assay on a BN II analyser (N Latex CRP mono, Dade Behring, Marburg, Germany). All laboratory analyses in both studies were done in a blinded fashion.

\section{Analysis of the $R(-I 3 I) \rightarrow H$ polymorphism of the FcyRlla gene in MONICA}

Genomic DNA has been isolated from white blood cells by standard methods [28]. FcyRIIa genotyping was performed with matrix-assisted laser desorption/ionisation time-of-flight (MALDI-TOF) mass spectrometry [29].

\section{Analysis of the $R(-I 3 I) \rightarrow H$ polymorphism of the Fc/RIIa gene in LURIC}

Genomic DNA was prepared from EDTA anticoagulated blood. Receptor polymorphism was determined from polymerase chain reaction and restriction typing. The primers for amplification were 5'-CCTTGGACAGTGATGGTCAC-3' and 5'-TGGAAAATCCCAGAAATTCTCGC-3'. Amplification products were digested with BstUI (New England BioLabs) and analysed by agarose gel electrophoresis. The G allele (H131) yielded fragments of 120 and $23 \mathrm{bp}$; the A allele (R131) was not digested (143 bp).

\section{Statistical analyses}

In both populations demographic, clinical and biochemical characteristics were compared in a descriptive way. Differences in genotype distribution among cases were compared with values predicted by the Hardy-Weinberg equilibrium. The odds ratio (OR) and 95\% confidence intervals (CI) for the presence of CHD were assessed by multivariable logistic regression analysis, adjusted for traditional cardiovascular risk factors, given the HH131 genotype compared to RR131 and/or RH131 genotypes. The 
following established risk factors were used in the fully adjusted models: in MONICA, age, sex, years of education, alcohol consumption, smoking status, BMI, history of hypertension, history of diabetes, HDLc; in LURIC, age, sex, smoking status, BMI, history of hypertension, history of diabetes, and HDLc. Finally, we calculated a power assessment: A two group Chi-square test based on a twosided $\alpha$ of 0.050 and a power of $80 \%$ was used to estimate which statistically significant excess risk (Odds ratio) between cases and control of each study could be detected at minimum based on the proportions of the genotype HH131 versus the other two genotypes combined.

\section{Results}

Table 1 shows demographic characteristics of the MONICA case-control study. The study participants were predominantly men $(88.4 \%)$. Patients on average had a lower school education, lower alcohol consumption, were more often current- or ex-smokers and also more often had a history of hypertension and DM. BMI and HDLC were similar in both groups. Patients had a geometric mean CRP plasma value of $2.06 \mathrm{mg} / \mathrm{L}$ and a mean total cholesterol value of $224 \mathrm{mg} / \mathrm{dl}$. The corresponding levels in controls were $1.49 \mathrm{mg} / \mathrm{L}$ for CRP and $241 \mathrm{mg} / \mathrm{dl}$ for total cholesterol. The lower level of total cholesterol in patients was due to a more frequent prescription of lipidlowering drugs.

Table 2 presents characteristics of participants of the LURIC study. Patients on average were three years older, were more often current- or ex- smokers, and more frequently had a history of hypertension and DM. BMI, HDLc and total cholesterol were similar in both groups. Lipid-lowering drugs, predominantly statins (>97\%), were used by $61.2 \%$ of CHD patients and by $22.2 \%$ of controls. While the average CRP level in patients was 2.86 $\mathrm{mg} / \mathrm{L}$ (CRP concentration of 1,278 CAD patients with > $50 \%$ stenosis with acute coronary syndromes, and unstable angina pectoris were disregarded) this value was 2.55 $\mathrm{mg} / \mathrm{L}$ in controls.

Table 3 shows the genotype frequencies of the Fc $\gamma$ RIIa gene among cases and controls. Genotype frequencies in cases and controls, in both populations, did not show a significant departure from the Hardy-Weinberg equilibrium. Furthermore, neither in the MONICA population, nor in the LURIC population a difference among cases and controls with respect to FcyRIIa genotypes existed ( $p$ $=0.86$ in MONICA and $\mathrm{p}=0.64$ in LURIC).

Table 4 presents the partially and fully adjusted ORs obtained by logistic regression analysis for the presence of CHD associated with FcrRIIa genotypes. In the MONICA population, the OR for the presence of CHD associated with the HH genotype was 0.92 (95\% CI, 0.65 to 1.31 ) after adjustment for age and gender and increased to 1.01 (95\% CI, 0.69 to 1.48 ) after adjustment for other covariates (Table 4). If the RR and the RH genotype were taken as reference, the OR associated with the $\mathrm{HH}$ genotype was 0.99 (95\% CI, 0.75 to 1.28 ) after adjustment for age and gender, and increased to 1.08 (95\% CI, 0.81 to 1.44 ) after additional adjustment for other covariates.

In the LURIC population, the OR for CHD associated with the HH genotype in the LURIC population was 0.99 (95\% CI, 0.81 to 1.12 ) after adjustment for age and gender and 1.01 (95\% CI, 0.82 to 1.25 ) after further adjustment for other traditional cardiovascular risk factors. Again, if the

Table I: Characteristics of Patients with CHD and Controls: MONICA Study

\begin{tabular}{lll}
\hline & CHD patients & Controls \\
\hline $\mathrm{n}$ & 527 & 527 \\
Age, $\mu(\mathrm{SD})$ & $56.4(7.1)$ & $56.3(7.0)$ \\
Males (\%) & 88.4 & 88.4 \\
School education 9 years or less (\%) & 66.2 & 58.8 \\
Average alcohol consumption per day (g) $\mu$ (SD) & $17.8(21.7)$ & $26.5(28.6)$ \\
Teetotalers (\%) & 29.1 & 19.9 \\
Smoking status (\%): & & 23.9 \\
$\quad$ current smoker & 14.6 & 35.5 \\
$\quad$ ex-smoker & 67.6 & 40.6 \\
$\quad$ never smoker & 21.8 & $28.3(4.0)$ \\
History of high blood pressure (\%) & $28.4(3.7)$ & 30.7 \\
History of diabetes mellitus (\%) & 54.8 & 7.0 \\
Total cholesterol, mg/dl $\mu$ (SD) & 15.8 & $240.6(47.0)$ \\
HDL cholesterol, mg/dl $\mu$ (SD) & $224.3(44.4)$ & $48.7(14.3)$ \\
CRP, mg/L $*$ & $46.9(14.3)$ & 1.5
\end{tabular}

\footnotetext{
* geometric mean; HDL: high-density lipoprotein. CRP: C-reactive protein
} 
Table 2: Characteristics of Patients with CHD and Controls: LURIC Study

\begin{tabular}{lll}
\hline & CHD patients & Controls \\
\hline $\mathrm{n}$ Age, $\mu(\mathrm{SD})$ & 2,227 & 1,032 \\
Males (\%) & $63.8(10.0)$ & $60.2(1 \mathrm{I} .4)$ \\
Smoking status (\%): & 77.3 & 53.9 \\
$\quad$ current smoker & 20.6 & 18.1 \\
$\quad$ ex-smoker & 49.8 & 32.7 \\
$\quad$ never smoker & 29.6 & 49.2 \\
Hody mass index $\left(\mathrm{kg} / \mathrm{m}^{2}\right), \mu(\mathrm{SD})$ & $27.5(3.9)$ & $27.6(4.4)$ \\
History of high blood pressure (\%) & 54.3 & 50.6 \\
Total cholesterol, mg/dl, $\mu$ (SD) & 36.6 & 21.8 \\
HDL cholesterol, mg/dl, $\mu$ (SD) & $189.5(39.2)$ & $198.7(37.4)$ \\
CRP, mg/L $*$ & $37.2(10.0)$ & $41.9(11.7)$ \\
\hline
\end{tabular}

* median and $25^{\text {th }}$ and $75^{\text {th }}$ percentile, respectively;

HDL: high-density lipoprotein. CRP: C-reactive protein

Table 3: Distribution of FcyRIla Genotypes and Alleles in CHD Patients and Age- and Gender-Matched Controls in Percent (\%): MONICA and LURIC Study

\begin{tabular}{|c|c|c|c|c|c|c|c|c|c|}
\hline \multirow[b]{3}{*}{ Genotype } & \multicolumn{9}{|c|}{ MONICA* } \\
\hline & \multicolumn{3}{|c|}{ Men } & \multicolumn{3}{|c|}{ Women } & \multicolumn{3}{|c|}{ All } \\
\hline & $\begin{array}{c}\text { Cases } \\
n=466\end{array}$ & $\begin{array}{c}\text { Controls } \\
n=466\end{array}$ & $\mathbf{P}$ & $\begin{array}{l}\text { Cases } \\
n=61\end{array}$ & $\begin{array}{c}\text { Controls } \\
n=61\end{array}$ & $\mathbf{P}$ & $\begin{array}{c}\text { Cases } \\
n=527\end{array}$ & $\begin{array}{c}\text { Controls } \\
n=527\end{array}$ & $\mathbf{P}$ \\
\hline RRI3 I & $20.6(n=96)$ & $19.5(n=91)$ & & $19.7(n=12)$ & $16.4(n=10)$ & & $20.5(n=108)$ & $19.1(n=101)$ & \\
\hline RHI3 I & $48.9(n=228)$ & $51.5(n=240)$ & & $59.0(n=36)$ & $47.5(n=29)$ & & $50.1(n=264)$ & $51.0(n=269)$ & \\
\hline HHI3 I & $30.5(n=142)$ & $28.9(n=135)$ & 0.73 & $21.3(n=13)$ & $36.1(n=22)$ & 0.19 & $29.4(n=155)$ & $29.8(n=157)$ & 0.86 \\
\hline \multicolumn{10}{|l|}{ Allele } \\
\hline $\mathbf{R}$ & $45.1(n=324)$ & $45.3(n=331)$ & & $49.2(n=48)$ & $40.2(n=39)$ & & $45.5(n=372)$ & $44.7(n=370)$ & \\
\hline $\mathbf{H}$ & $54.9(n=370)$ & $54.7(n=375)$ & & $50.8(n=49)$ & $59.8(n=5 I)$ & & $54.5(n=419)$ & $55.3(n=426)$ & \\
\hline & \multicolumn{9}{|c|}{ LURIC* } \\
\hline & \multicolumn{3}{|c|}{ Men } & \multicolumn{3}{|c|}{ Women } & \multicolumn{3}{|c|}{ All } \\
\hline Genotype & $\begin{array}{c}\text { Cases } \\
n=1722\end{array}$ & $\begin{array}{l}\text { Controls } \\
n=556\end{array}$ & $\mathbf{P}$ & $\begin{array}{c}\text { Cases } \\
n=505\end{array}$ & $\begin{array}{l}\text { Controls } \\
n=476\end{array}$ & $\mathbf{P}$ & $\begin{array}{c}\text { Cases } \\
n=2227\end{array}$ & $\begin{array}{l}\text { Controls } \\
n=1032\end{array}$ & $\mathbf{P}$ \\
\hline RRI3। & $21.1(n=363)$ & $20.0(n=111)$ & & $18.4(n=93)$ & $19.1(n=93)$ & & $20.5(n=456)$ & $19.6(n=202)$ & \\
\hline RHI3I & $49.1(n=846)$ & $47.1(n=262)$ & & $47.7(n=24 I)$ & $49.4(n=235)$ & & $48.8(n=1087)$ & $48.2(n=497)$ & \\
\hline HHI3I & $29.8(n=513)$ & $32.9(n=183)$ & 0.38 & $33.9(n=17 \mid)$ & $31.5(n=150)$ & 0.74 & $30.7(n=684)$ & $32.3(n=333)$ & 0.64 \\
\hline \multicolumn{10}{|l|}{ Allele } \\
\hline $\mathbf{R}$ & $45.6(n=1209)$ & $43.5(n=373)$ & & $42.3(n=334)$ & $43.8(n=328)$ & & $44.9(n=1543)$ & $43.7(n=699)$ & \\
\hline $\mathbf{H}$ & $54.4(n=1359)$ & $56.5(n=445)$ & & $57.7(n=4 \mid 2)$ & $56.2(n=385)$ & & $55.1(n=|77|)$ & $56.3(n=830)$ & \\
\hline
\end{tabular}

*The genotype distribution in LURIC as well as in the MONICA study was in Hardy-Weinberg equilibrium among both patients and controls. 
Table 4: Partly and Fully Adjusted Odds Ratios for CHD Associated With FcyRIla Genotypes: MONICA and LURIC Study

\begin{tabular}{|c|c|c|}
\hline Genotype & Partly-adjusted OR $(95 \% \mathrm{Cl})$ & Multivariable-adjusted OR $(95 \% \mathrm{Cl})$ \\
\hline \multicolumn{3}{|c|}{ MONICA* } \\
\hline $\mathbf{R R}|\mathbf{3}|$ & I reference & I reference \\
\hline RHI3 I & $0.92(0.66-1.26)$ & $0.91(0.65-1.29)$ \\
\hline HHI3I & $0.92(0.65-|.3|)$ & $1.01(0.69-1.48)$ \\
\hline RR or RH | 3 | & I reference & I reference \\
\hline HHI3I & $0.99(0.75-1.28)$ & $1.08(0.8 \mathrm{I}-1.44)$ \\
\hline \multicolumn{3}{|c|}{ LURIC** } \\
\hline RRI3। & I reference & I reference \\
\hline RHI3I & $0.95(0.76-1.18)$ & $0.97(0.77-1.21)$ \\
\hline HHI3I & $0.99(0.8 \mathrm{I}-1.12)$ & $1.01(0.82-1.25)$ \\
\hline $\mathbf{R R}$ or $\mathbf{R H} \mid \mathbf{3}$ | & I reference & I reference \\
\hline HHI3I & $0.96(0.81-1.13)$ & $0.96(0.8 I-1.14)$ \\
\hline
\end{tabular}

*Partly-adjusted for age and gender; Multivariable-adjusted for age, gender, years of education, alcohol consumption, smoking status, BMI, history of hypertension and diabetes, HDL-cholesterol **Partly-adjusted for age and gender; Multivariable-adjusted for age, gender, smoking status, body mass index, history of hypertension, history of diabetes, HDL-cholesterol

RR and RH genotypes were taken as reference, the OR for the association of CHD with the HH genotype was 0.96 (95\% CI, 0.81 to 1.13 ) after partial adjustment for age and gender, and did not change $(0.96,95 \% \mathrm{CI}, 0.81$ to 1.14$)$ after multivariable adjustment.

\section{Discussion}

We expected carriers of the HH131 genotype to have a lower risk of CHD because of the strongly decreased binding of CRP to cells expressing the specific FcyIla receptor. However, results from these two large independent casecontrol studies do not suggest that the HH131 genotype of Fc $\gamma$ RIIa may be associated with a lower risk of CHD.

\section{Association between Fc/RIla genotype and CHD}

Recently published experimental data are in support of the negative findings in our populations. It was shown that CRP binding to monocytes from R131 homozygotes and RH131 heterozygotes was dose-dependent and saturable at approximately $100 \mathrm{mg} / \mathrm{L}$ of CRP. The binding avidities of CRP for monocytes from R131 homozygous and RH131 heterozygous donors were 24 and $75 \mathrm{mg} / \mathrm{L}$, respectively [24]. This value is in the range of CRP concentrations present in sera from patients with rather mild to moderate acute phase responses than concentrations postulated in CAD [30]. Since average CRP levels in both populations were less than $4 \mathrm{mg} / \mathrm{L}$, and monocytes from R131 homozygotes bound CRP with an high apparent affinity of $24 \mathrm{mg} / \mathrm{L}$, receptor kinetics do not allow a significant increase in receptor up-regulation. These results are concordant with the observation, that maximum levels of signalling response of Fc $\gamma$ RIIa to CRP in differentiated HL-60 granulocytes was recorded at $100-200 \mathrm{mg} / \mathrm{L}$. Thus, one can hypothesize that, although having a lower affinity for the potentially pro-atherogenic CRP, individuals bearing the H131 allele do not benefit, since the concentration of CRP is too low to rise the receptor level in atherosclerotic plaque sufficiently.

As expected, crystal structure analyses showed that the amino-acid position 131 is critical for the interaction with the IgG-Fc-tail [31], and the allelic variants of the Fc $\gamma$ R possess distinct phagocytic capacities. The H131 allele is the only Fc $\gamma$ R that recognizes IgG2 efficiently, which is the main antibody subtype directed against encapsulated bacteria [9]. In certain conditions gram-negative bacteria may get into the circulation on a daily basis, and thereby stimulate IgG2 production, which plays a pivotal role in phagocytosis of such bacteria [32]. Inflammation, an essential feature in atherosclerosis may be triggered by infectious pathogens $[33,34]$. It was thought that atherosclerotic cells expressing the HH131 genotype may be less capable for atherosclerosis by being more effective in cleaning IgG2 immune complexes. Several in vitro studies demonstrated reduced phagocytosis of IgG2-opsonized particles in cells from individuals homozygous for FcyRIIa-R131 [35]. However, this needs to be discussed critically, as the possibility of CRP-mediated phagocytosis was not taken into consideration sufficiently. CRP binds to encapsulated bacteria like $S$. pneumoniae and $H$. influenza, and maybe in this way provides partial protection from encapsulated infectious pathogens in individuals bearing the R131 allele of Fc $\gamma$ RIIa, contributing to a reduction of atherosclerotic risk [24]. The opsonization of $S$. 
pneumoniae, in the presence of $\mathrm{CRP}$, primarily activates the classical complement pathway and complement is required for the protection by CRP. However, CRP protection does not require $F c \gamma R$, indicating that CRP is not primarily protective by direct opsonization but by complement and the subsequent opsonophagocytosis [36]. CRP and complement were also shown to be necessary for serum bactericidal activity against $H$. influenza. Using a CRP transgenic mouse model, CRP has also been shown to be protective against gram-negative bacterium [37-39]. This counterbalance of different CRP bindingcapacities may affect the contribution of Fc $\gamma$ RIIa alleles to host defense and autoimmunity.

In summary, one can hypothesize that there is a critical counterbalance between complement activation by CRP and subsequent protection of bacteria-induced inflammation and cardiovascular disease and the proatherogenic role of CRP in both, the case of strong binding and the case of weak binding of CRP.

Recently three studies suggested the possibility that Fc $\gamma$ RI could be the high-affinity receptor for CRP [40-42]. Using ultrasensitive confocal fluorescence microscopy they demonstrated that CRP indeed does bind to FcyRIIa, although with lower affinity than described earlier. Furthermore they studied CRP binding to transfected COS-7 cells expressing the high-affinity IgG receptor Fc $\gamma$ RI. They showed that CRP binds to Fc $\gamma$ RI on intact cells, with a kd of $10 \pm 3 \mu \mathrm{mol} / \mathrm{L}$. Transfection of COS-7 cells with a plasmid coding for both Fc $\gamma$ RI and its functional counterpart, the $\gamma$-chain, markedly increased CRP affinity to Fc $\gamma$ RI, resulting in a $\mathrm{kd}$ of $0.35 \pm 0.10 \mu \mathrm{mol} / \mathrm{L}$. However, results of the recently published studies remain controversial, therefore further research is needed before Fc $\gamma \mathrm{RI}$ might be established as a high-affinity receptor for CRP.

\section{Strengths and limitations of our study}

Our study has several strengths that need to be mentioned. We carefully selected cases and controls and, in addition, we extensively recorded conventional risk factors in order to assess their potential for confounding and carried out adjustments in multivariate models. The large sample sizes and the independency of the two populations also contribute to the strength of this study. In the MONICA population, all analyses were done in patients with a history of prior MI and compared to populationbased controls. In the LURIC population, consecutive cases with angiographically proven stenosis of a major coronary artery of at least $50 \%$ were included. Since the Fc $\gamma$ RIIa could not be found in mice, such well designed epidemiological studies are of considerable interest in investigating the receptor.
Our study also has some limitations. We used a case-control design in both populations, therefore the temporal relationship of the plasma parameters and disease is difficult to establish. However the temporal relationship of genotype and CHD is certain. Selection and survival bias may represent a further problem. The appropriateness of the control group of the LURIC study deserves discussion. Early lesions undetectable by angiography could not be ruled out in controls, nor was coronary microvascular dysfunction. Nevertheless, coronary angiography remains the gold standard for the diagnosis of clinically relevant CAD, and it is well known that the future incidence of cardiac events is low in subjects with normal coronary angiograms. Although the present study did not have the power to detect a very weak association between Fc $\gamma$ RIIa genotypes (i.e. HH131 vs. others) and CHD, it had a power of $80 \%$ to detect an OR of $1.46(\alpha=0.05)$ or larger in the MONICA study and an OR of 1.26 or larger in the LURIC study.

\section{Conclusion}

Our results do not suggest an independent and clinically relevant relationship of the Fc $\gamma$ RIIa gene polymorphism with risk of CAD. Consequently, it seems unlikely that, in the population studied, Fc $\gamma$ RIIa R(-131) $\rightarrow$ H genotype represents a promising tool for identifying those at increased risk for CHD.

\section{Abbreviations}

AAI: ankle-arm index; ADA: American Diabetes Association; AHA: American Heart Association; BMI: body mass index; $\mathrm{CAD}$ : coronary artery disease; $\mathrm{CHD}$ : coronary heart disease; CI: confidence interval; CRP: C-reactive protein; DM: diabetes mellitus; EC: endothelial cell; ERK: extracellular signal-regulated kinase; HAEC: human aortic endothelial cell; HDLc: high-density lipoprotein cholesterol; ICAM: intercellular adhesion molecule; Ig: immunoglobulin; IL: interleukin; KORA: Cooperative Research in the Region of Augsburg; LDLc: low-density lipoprotein cholesterol; LURIC: LUdwigshafen RIsk and Cardiovascular Health; MI: myocardial infarction; MMP: matrix metalloproteinase; MONICA: MOnitoring trends and determinants in CArdiovascular disease; OR: odds ratio; PAI: plasminogen activator inhibitor; TNF: tumour necrosis factor; VCAM: vascular cell adhesion molecule.

\section{Competing interests}

The authors declare that they have no competing interests.

\section{Authors' contributions}

MK drafted the manuscript. TI, CV, WM and MHH carried out molecular genetic studies, participated in the study design and coordination. DR and WM analysed the data. $\mathrm{BB}, \mathrm{CM}, \mathrm{BW}$ and NK contributed to sample collection and critically revised the manuscript. WK conceived the study 
and critically revised the manuscript. All authors read and approved the final manuscript.

\section{Acknowledgements}

The authors would like to thank all participants of the MONICA and LURIC studies. We are grateful to Mrs. Gerlinde Trischler for excellent technical assistance.

\section{References}

I. Schreiber AD, Rossman MD, Levinson Al: The immunobiology of human Fc gamma receptors on hematopoietic cells and tissue macrophages. Clin Immunol Immunopathol 1992, 62:66-72.

2. Ravetch JV, Kinet JP: Fc receptors. Annu Rev Immunol 199I, 9:457-492

3. Hulett MD, Hogarth PM: Molecular basis of Fc receptor function. Adv Immunol 1994, 57: I- 127.

4. Hibbs ML, Bonadonna L, Scott BM, McKenzie IF, Hogarth PM: Molecular cloning of a human immunoglobulin G Fc receptor. Proc Natl Acad Sci USA 1988, 85(7):2240-2244.

5. Cassel DL, Keller MA, Surrey S, Schwartz E, Schreiber AD, Rappaport EF, McKenzie SE: Fluorescence-based RT PCR analysis: determination of the ratio of soluble to membrane-bound forms of Fc gamma RIIA transcripts in hematopoietic cell lines. PCR Methods Appl 1993, 3(1):32-38.

6. Ratcliffe NR, Kennedy SM, Morganelli PM: Immunocytochemical detection of Fcgamma receptors in human atherosclerotic lesions. Immunol Lett 200I, 77(3):169-I74.

7. Calverley DC, Brass E, Hacker MR, Tsao-Wie DD, Espina BM, Pullarkat VA, Hodis HN, Groshen S: Potential role of platelet FcgammaRIIA in collagen-mediated platelet activation associated with atherothrombosis. Atherosclerosis 2002, 164(2):261-267.

8. Pfeiffer JR, Howes PS, Waters MA, Hynes ML, Schnurr PP, Demidenko E, Bech FR, Morganelli PM: Levels of expression of Fcgamma receptor IIA (CD32) are decreased on peripheral blood monocytes in patients with severe atherosclerosis. Atherosclerosis 200I, I55(I):2II-218.

9. Warmerdam PA, Winkel JG van de, Vlug A, Westerdaal NA, Capel PJ: A single amino acid in the second Ig-like domain of the human Fc gamma receptor II is critical for human IgG2 binding. J Immunol I99|, |47(4): I338-I343.

10. Hansson GK, Libby P, Schönbeck U, Yan ZQ: Innate and adaptive immunity in the pathogenesis of atherosclerosis. Circ Res 2002, $91: 28|-29|$.

11. Hansson GK: Immune mechanisms in atherosclerosis. Arterioscler Thromb Vasc Biol 200 I, 2I(1 2): 1876-1890.

12. Meer IM van der, Witteman JC, Hofman A, Kluft C, de Maat MP: Genetic variation in Fcgamma receptor lla protects against advanced peripheral atherosclerosis. The Rotterdam Study. Thromb Haemost 2004, 92(6): 1273-1276.

13. Gavasso S, Nygard O, Pedersen ER, Aarseth JH, Bleie O, Myhr KM, Vedeler CA: Fcgamma receptor IIIA polymorphism as a riskfactor for coronary artery disease. Atherosclerosis 2005, I 80(2):277-282.

14. Bharadwaj D, Stein MP, Volzer M, Mold C, Du Clos TW: The major receptor for C-reactive protein on leukocytes is fcgamma receptor II. J Exp Med 1999, 190(4):585-590.

15. Pan LF, Kreisle RA, Shi YD: Detection of Fcgamma receptors on human endothelial cells stimulated with cytokines tumour necrosis factor-alpha (TNF-alpha) and interferon-gamma (IFN-gamma). Clin Exp Immunol 1998, I I 2(3):533-8.

16. Gabay C, Kushner I: Acute-phase proteins and other systemic responses to inflammation. N Engl J Med 1999, 340(6):448-54.

17. Koenig W, Lowel H, Baumert J, Meisinger C: C-reactive protein modulates risk prediction based on the Framingham Score: implications for future risk assessment: results from a large cohort study in southern Germany. Circulation 2004, 109:1349-1353.

18. Koenig W, Pepys MB: CRP risk prediction: low specificity, high sensitivity. Ann Intern Med 2002, I 36:550-552.

19. Paul A, Ko KW, Li L, Yechoor V, McCrory MA, Szalai AJ, Chan L: Creactive protein accelerates the progression of atherosclerosis in apolipoprotein E-deficient mice. Circulation 2004, I09(5):647-655.
20. Torzewski M, Rist C, Mortensen RF, Zwaka TP, Bienek M, Waltenberger J, Koenig W, Schmitz G, Hombach V, Torzewski J: C-reactive protein in the arterial intima: role of $C$-reactive protein receptor-dependent monocyte recruitment in atherogenesis. Arterioscler Thromb Vasc Biol 2000, 20(9):2094-2099.

21. Reynolds GD, Vance RP: C-reactive protein immunohistochemical localization in normal and atherosclerotic human aortas. Arch Pathol Lab Med 1987, I I I (3):265-269.

22. Devaraj S, Du Clos TW, jialal I: Binding and internalization of C. reactive protein by Fcgamma receptors on human aortic endothelial cells mediates biological effects. Arterioscler Thromb Vasc Biol 2005, 25(7): | 359-| 363.

23. Williams TN, Zhang CX, Game BA, He L, Huang Y: C-reactive protein stimulates MMP-I expression in $U 937$ histiocytes through Fc[gamma]RII and extracellular signal-regulated kinase pathway: an implication of CRP involvement in plaque destabilization. Arterioscler Thromb Vasc Biol 2004, 24(I):6 I-66.

24. Stein MP, Edberg JC, Kimberly RP, Mangan EK, Bharadwaj D, Mold C, Du Clos TW: C-reactive protein binding to FcgammaRIla on human monocytes and neutrophils is allele-specific. J Clin Invest 2000, 105(3):369-376.

25. Keil U, Liese AD, Hense HW, Filipiak B, Doring A, Stieber J, Lowel H: Classical risk factors and their impact on incident non-fatal and fatal myocardial infarction and all-cause mortality in southern Germany. Results from the MONICA Augsburg cohort study 1984-1992. Eur Heart J. 1988, 19(8): | | 97-| 207.

26. Tunstall-Pedoe $\mathrm{H}$, the WHO MONICA Project Principal Investigators: The World Health Organization MONICA Project (Monitoring of Trends and Determinants in Cardiovascular Disease): a major international collaboration. J Clin Epidemiol. 1988, 4I(2): I05-I| 4.

27. Winkelmann BR: Genomics and large scale phenotypic databases. Pharmacogenomics 200I, 2(I):3-5.

28. Miller SA, Dykes DD, Polesky HF: A simple salting out procedure for extracting DNA from human nucleated cells. Nucleic Acids Res 1998, I6(3): 1215.

29. Fannon WR: Single nucleotide polymorphism (SNP) analysis of a variety of non-ideal DNA sample types by SEQUENOM MALDI-TOF. Proc Am Assoc Cancer Res 2002, 43:53

30. Koenig W, Sund M, Frohlich M, Fischer HG, Lowel H, Doring A, Hutchinson WL, Pepys MB: C-Reactive protein, a sensitive marker of inflammation, predicts future risk of coronary heart disease in initially healthy middle-aged men: results from the MONICA (Monitoring Trends and Determinants in Cardiovascular Disease) Augsburg Cohort Study, 1984 to 1992. Circulation 1999, 99(2):237-242.

3I. Maxwell KF, Powell MS, Hulett MD, Barton PA, McKenzie IF, Garrett TP, Hogarth PM: Crystal structure of the human leukocyte Fc receptor, Fc gammaRIla. Nat Struct Biol 1999, 6(5):437-442.

32. Siber GR, Schur PH, Aisenberg AC, Weitzman SA, Schiffman G: Correlation between serum IgG-2 concentrations and the antibody response to bacterial polysaccharide antigens. $N$ Engl J Med 1980, 303(4): 178-182.

33. Ross R: Atherosclerosis-an inflammatory disease. N EnglJ Med 1999, 340(2): II I-126.

34. Libby P, Egan D, Skarlatos S: Roles of infectious agents in atherosclerosis and restenosis: an assessment of the evidence and need for future research. Circulation 1997, 96(II):4095-4I03.

35. Dahmer MK, Randolph A, Vitali S, Quasney MW: Genetic polymorphisms in sepsis. Pediatr Crit Care Med 2005, 6(3 Suppl):6 I-73.

36. Marnell L, Mold C, Du Clos TW: C-reactive protein: Ligands, receptors and role in inflammation. Clinical Immunology 2005, II7:104-III.

37. Szalai AJ, VanCott JL, McGhee JR, Volanakis WH: Human C-reactive protein is protective against fatal Salmonella enterica Serovar Typhimurium infection in transgenic mice. Infect Immun 2000, 68:5652-5656.

38. Mortensen RF, Osmand AP, Lint TF, Gewurz H: Interaction of Creactive protein with lymphocytes and monocytes: complement-dependent adherence and phagocytosis. J Immunol 1976 , II 7(3):774-78I.

39. Kindmark CO: Stimulating effect of C-reactive protein on phagocytosis of various species of pathogenic bacteria. Clin Exp Immunol I 97I, 8(6):94I-948.

40. Manolov DE, Röcker C, Hombach V, Nienhaus GU, Torzewski J: Ultrasensitive confocal fluorescence microscopy of C-reac- 
tive protein interacting with Fc $\gamma \mathbf{R}$ Ila. Arterioscler Thromb Vasc Biol 2004, 24:2372-2377.

4I. Röcker C, Manolov DE, Kuzmenkina EV, Tron K, Slatosch H, Torzewski J, Nienhaus GU: Affinity of C-reactive protein toward $\mathbf{F} \boldsymbol{c} \gamma \mathbf{R I}$ is strongly enhanced by the $\gamma$-chain. Am J Pathol 2007, 170:755-763.

42. Tron K, Manolov DE, Röcker C, Kächele M, Torzewski J, Nienhaus GU: C-reactive protein specifically binds to Fc gamma receptor type I on a macrophage-like cell line. Eur J Immunol 2008, 38(5): $|4| 4-22$.

\section{Pre-publication history}

The pre-publication history for this paper can be accessed here:

http://www.biomedcentral.com/1471-2350/10/46/pre pub

Publish with Bio Med Central and every scientist can read your work free of charge

"BioMed Central will be the most significant development for disseminating the results of biomedical research in our lifetime."

Sir Paul Nurse, Cancer Research UK

Your research papers will be:

- available free of charge to the entire biomedical community

- peer reviewed and published immediately upon acceptance

- cited in PubMed and archived on PubMed Central

- yours - you keep the copyright

Submit your manuscript here:

http://www.biomedcentral.com/info/publishing_adv.asp 